

Becker, Johannes and Peichl, Andreas and Rincke, Johannes:

Politicians' Outside Earnings and Electoral Competition

Munich Discussion Paper No. 2008-6

Department of Economics

University of Munich

Volkswirtschaftliche Fakultät

Ludwig-Maximilians-Universitäł München

Online at https://doi.org/10.5282/ubm/epub.2206 


\title{
Politicians' outside earnings and electoral competition
}

\author{
Johannes Becker* \\ Andreas Peichl \\ Johannes Rincke \\ University of Cologne \\ University of Cologne \\ University of Munich
}

This version: 11th March 2008

\begin{abstract}
This paper deals with the impact of electoral competition on politicians' outside earnings. We propose a simple theoretical model with politicians facing a tradeoff between allocating their time to political effort or to an alternative use generating outside earnings. The model has a testable implication stating that the amount of time spent on outside work is negatively related to the degree of electoral competition. We test this implication using a new dataset on outside earnings of members of the German federal assembly. Taking into account the potential endogeneity of measures of political competition that depend on past election outcomes, we find that politicians facing low competition have substantially higher outside earnings.
\end{abstract}

JEL Classification: D72, J45

Keywords: $\quad$ Political competition, outside earnings, political rents

*Corresponding author. Postal address/contact: Department of Economics, University of Cologne, MeisterEkkehart-Str. 11, 50931 Cologne. Phone: +49 221470 6200, email: johannes.becker@uni-koeln.de 


\section{Introduction}

The conflict of interests between voters as principals and elected politicians as agents is an old theme. While voters are concerned with electing competent representatives, they cannot directly observe effort and ability. In general, this lack of monitoring and the resulting asymmetric information allows elected politicians to extract rents. These rents may take various forms, such as pork-barrel projects, corruption, or slack to cultivate private affairs. The most important mechanism that helps voters to keep elected officials accountable for their actions is electoral competition. While there is a sizable theoretical literature on the effects of different electoral rules on the level of rent extraction ${ }^{1}$ and a number of empirical studies using macro data ${ }^{2}$, there are few empirical studies that provide micro-evidence on the relation between forms and intensity of electoral competition and the behavior of politicians.

One potentially important dimension of diverging interests between elected representatives and voters is the opportunity of politicians to engage in private sector activities to earn outside income. Interestingly, in most democracies elected politicians such as members of parliament can legally work in the private sector. It has been noted that the opportunity of elected officials to keep private sector jobs and corresponding income may well have positive effects on the overall quality of policymaking. For instance, if high-ability citizens can keep outside earnings while appointed in parliament, they will be more likely to run for public office. Hence, outside earnings may increase the average quality of politicians (Gagliarducci et al., 2007a). In contrast, for given ability, if politicians devote part of their time to private sector work, this will reduce the quality of policymaking. ${ }^{3}$

This paper uses micro-data to investigate the role of electoral competition for the tradeoff between political activities and work that generates outside earnings. The general idea behind this is straightforward: While voters usually cannot observe the amount of time devoted to outside work, they can punish politicians for neglecting their responsibilities and pursuing their private business by voting them out of office. Consequently, when deciding on the optimal level of private sector activities, elected politicians will weigh the gains from outside work against the increased risk of not getting reelected. If electoral competition is low, the probability of reelection is high, and the marginal benefit from political activity is low. In contrast, if

\footnotetext{
${ }^{1}$ See e.g. Persson and Tabellini (1999, 2000) and Myerson (1993).

${ }^{2}$ Examples are Persson and Tabellini (2003), Kunicova and Rose-Ackerman (2005) as well as Milesi-Ferretti, Perotti and Rostagno (2002).

${ }^{3}$ We do not discuss the case where politicians are influenced by or even get financially dependent on special interest groups. For related evidence, see Couch, Atkinson and Shughart (1992), analyzing how politicians who are on the payroll of higher education institutions affect public funding per college student.
} 
competition is fierce and electoral races are close, the marginal benefit of political work tends to be high. Consequently, electoral competition affects the tradeoff between political activity and work in the private sector. If competition gets stronger, politicians re-allocate time from outside work towards political activity, and outside earnings decrease. In this perspective, electoral competition limits political rents.

Our contribution to the literature is two-fold. Firstly, we set up a simple theoretical framework that allows us to address the tradeoff between outside earnings and reelection prospects. The model predicts that politicians facing strong political competition should devote less time to outside work. In the second part of the paper, we take this prediction to real data. Using a unique dataset covering all members of the German Bundestag and providing detailed information on outside earnings for the years 2005-07, we test whether the degree of electoral competition has any effect on outside earnings. Our identification strategy accounts for the fact that measures of electoral competition are likely to be endogenous in an empirical model of outside earnings. Exploiting the fact that in German federal elections, voters cast one vote to elect a candidate representing the electoral district and a second vote to determine the strength of parties in the Bundestag, we construct instrumental variables for the degree of electoral competition at the district level. Our results point to a significant impact of electoral competition on outside earnings. An increase in the vote margin in the next preceding election by one standard deviation is estimated to increase outside earnings over a four-year term by 18,000 to 19,200 Euros on average.

The paper is related to a number of important contributions dealing with the selection of citizens into political careers and the decision of elected officials how to allocate time to different activities. The latter decision is addressed by Besley (2004) who builds a principal-agent model in which the effect of higher wages on politicians' activities can be analyzed. Gagliarducci et al. (2007b) show that Italian politicians who are elected by majority rule show higher effort levels (lower absenteeism) than politicians who are elected in a proportional system. The voting behavior of members of the U.S. Senate is analyzed in Rosenson (2007). Among other things, the author finds that electorally vulnerable members were less likely to support legislation limiting honoraria income. Parker (1992) offers a general discussion of the determinants of honoraria income among members of the U.S. Congress, finding no effect of electoral competition. In Gagliarducci et al. (2007a), the authors point to a positive relation between outside income and absenteeism and discuss the role of outside earnings in the process of self-selection of citizens into political careers. The latter issue is also analyzed by Fiorina (1994) who explains the phenomenon of divided government in the US, arguing that professional careers as politicians are more attractive to Democrats than to Republicans. He finds that higher compensation 
increases the number of Democrats in legislation. Part of the analysis in Besley (2004) is concerned with the decision of high-ability-citizens to candidate for office, see also Besley (2005) as well as Poutvaara and Takalo (2007). Further contributions in this field are Messner and Polborn (2004), Caselli and Morelli (2004), as well as Mattozzi and Merlo (2007a, 2007b).

The remainder of the paper is organized as follows. In the next section, we propose a simple theoretical model with politicians facing a tradeoff between allocating their time to political effort and an alternative use generating outside earnings. Section 3 describes the institutional background, the empirical model and the data including some descriptive statistics. The results of our empirical analysis are presented in Section 4. Section 5 concludes.

\section{The model}

Consider a representative two-period-lived politician who receives utility from consumption and from being in office. In both periods, she is endowed with one unit of time. In the first period, she decides how to allocate time to political effort $t_{1}$ and private sector work $1-t_{1}$. Whereas $t_{1}$ increases the probability of being (re)elected to hold office in period $2,1-t_{1}$ increases earnings. Let $w$ denote the outside occupation's wage rate of the incumbent and $\omega$ the (regular) occupation's wage rate of the challenger. The compensation payed to politicians for holding office is $W$. This compensation is fixed, i.e. it does not depend on the amount of time allocated to political effort. For the sake of completeness, let $\Omega$ be an equivalent lump-sum income of the challenger.

Let $C_{1}$ and $C_{2}$ denote consumption in period 1 and 2 , respectively. The first period budget constraint is then given by $C_{1}=W+w\left(1-t_{1}\right)$ if the politician is in office, and $C_{1}=\Omega+$ $\omega\left(1-t_{1}\right)$ otherwise. In contrast, the second period budget constraint depends on the outcome of the election which is assumed to take place between period 1 and 2 . If the politician is (re)elected, the level of second period consumption is given by $C_{2}=W+w$ and $C_{2}=\Omega+\omega$ otherwise. Here, we used $t_{2}=0$ which reflects that politicians have no incentive to allocate time to political effort in the second period.

In the following, we will differentiate between two types of politicians, $i=A, B$, the incumbent $A$ who holds office in period 1 and the challenger $B$. Each politician $i$ maximizes her expected utility as given by

$$
\max _{t_{1}^{i}} E\left(U^{i}\right)=\pi^{i} U\left(C_{1}^{i}, W+w^{i}, \gamma^{i}\right)+\left(1-\pi^{i}\right) U\left(C_{1}^{i}, \Omega^{i}+\omega^{i}, 0\right)
$$


where $\pi^{i}=\pi^{i}\left(t_{1}^{i}\right)$ is the probability of reelection which is a function of first-period political effort $t_{1}^{i}$. The preference parameter $\gamma^{i}$ measures the non-pecuniary value of being in office. $U$ is assumed to be increasing, strictly concave and separable in both $C_{1}, C_{2}$ and $\gamma$. For simplicity, we assume that the cross-derivatives are zero.

The optimal choice of $t_{1}^{i}$ is given by

$$
\frac{\partial E\left(U^{i}\right)}{\partial t_{1}^{i}}=\frac{\partial C_{1}^{i}}{\partial t_{1}^{i}} U_{C_{1}^{i}}+\pi^{i \prime}\left(U^{i, e}-U^{i, n e}\right)=0
$$

where $\frac{\partial C_{1}^{i}}{\partial t_{1}^{i}}=-w^{i}$ in case of the incumbent and $\frac{\partial C_{1}^{i}}{\partial t_{1}^{i}}=-\omega^{i}$ in case of the challenger. $U^{i, e}=$ $U\left(C_{1}^{i}, W+w^{i}, \gamma^{i}\right)$ denotes the utility when being elected and $U^{i, n e}$ the utility when not being elected. Thus, the optimal choice equalizes the marginal benefits from political effort and outside work in period 1 . The marginal benefit from outside work is simply the marginal utility from period-1 consumption times the wage under consideration, $w$ or $\omega$, respectively, see the first term on the right hand side. The marginal benefit from political effort is given by its marginal effect on the reelection probability $\pi^{i \prime}$ times the utility difference. Note that, given $\pi^{i \prime}>0$, a positive amount of time spent for political work, $t_{1}^{i}>0$, requires $U^{i, e}-U^{i, n e}>0$, i.e. the politician has to assign a higher utility to being in office than to losing the election and working in her former profession. This is satisfied for sufficiently high levels of $\gamma^{i}$.

How does political competition look like? The incumbent and the challenger compete for a constituency. In the following, we will consider the case, in which both politicians have identical preferences and wage rates are equal: $w^{A}=\omega^{B}$ and $W=\Omega^{B}$. The appendix discusses some implications of relaxing this assumption. In order to determine the election probability $\pi\left(t_{1}\right)$, we assume that a candidate wins if she gets more than 50 per cent of the votes. Candidate A's fraction $x$ of overall votes can be modelled as

$$
x^{A}=0.5+\mu+f\left(t_{1}^{A}-t_{1}^{B}\right)+\varepsilon
$$

where $\mu$ is a measure for $A$ 's advantage over $B$ in case of equal levels of political effort, with $-0.5<\mu^{-} \leq \mu \leq \mu^{+}<0.5$ where $\mu^{-}$and $\mu^{+}$are the minimum and the maximum values of $\mu$. The function $f\left(t_{1}^{A}-t_{1}^{B}\right)$ depicts the effect of political effort on the voting result, with $f(0)=0$ and $f^{\prime}>0>f^{\prime \prime}$. $\varepsilon$ is a stochastic shock which cannot be influenced by the candidates. The $\mathrm{CDF}$ of $\varepsilon$ is $\Phi(\varepsilon)$ and is assumed to be symmetric and unimodal with $\Phi(0)=0.5$. We assume that the sum of $f($.$) and \varepsilon$ is always small enough to prevent $x^{A}$ to become negative or exceed 
unity. The probability of winning the election is thus given by

$$
\pi^{A}(x \geq 0.5)=1-\Phi\left(-\mu-f\left(t_{1}^{A}-t_{1}^{B}\right)\right)
$$

Thus, the marginal effect of political effort on the reelection probability increases in the density $\Phi^{\prime}$ and the marginal effectivity $f^{\prime}$. Since both politicians are identical and $\pi^{A}=1-\pi^{B}$, as well as $\pi^{A \prime}=\pi^{B \prime}$ due to symmetry, both politicians will always spend the same amount of time for political effort. That means, in equilibrium $f\left(t_{1}^{A}-t_{1}^{B}\right)=0$. If $w^{i} \neq \omega^{i}$ and/or $W \neq \Omega^{i}$, this may not be the case. The appendix shows, though, that our results do not depend on the symmetry assumption although it facilitates notation.

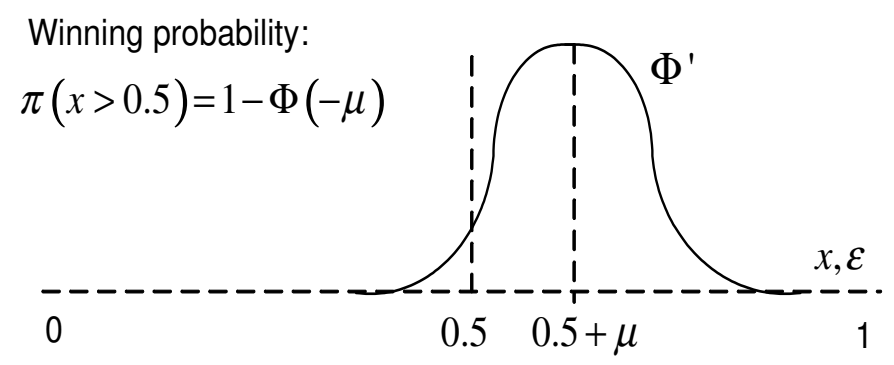

Figure 1: Candidate A's probability of winning the election.

Figure 1 shows a possible density function $\Phi^{\prime}(\varepsilon)$. The surface beneath the density function for levels below 0.5 is equivalent to the probability that candidate A loses. In other words, the larger $\mu$, the higher the probability that candidate A wins, see equation (4). It is a crucial, though plausible, assumption that small deviations of $\varepsilon$ from zero have a higher density than large deviations. Under this assumption, the slope of the density function is positive, $\Phi^{\prime \prime}>0$, for all positive values of $\mu$.

Comparative static analysis shows that an increase in the politicians' remuneration increases the time spent for political activities via two channels, $\frac{d t_{1}^{A}}{d W}, \frac{d t_{1}^{B}}{d W}>0$, as the appendix shows. Firstly, due to the concavity of the utility function, more income in period 1 weakens the incumbent's incentive to increase outside earnings. Secondly, it makes being reelected more attractive to both candidates.

Furthermore, increasing the wage rate of outside occupations has an ambiguous effect on both candidates. As it is shown in the appendix, the incumbent has more incentive to replace political work by outside occupations since it is better paid, but being reelected gets more attractive which increases the incentive to spend time for political work. The challenger faces higher incentives for political work because the political office is associated with higher income, 
but, if the incumbent reduces political effort, the challenger may herself reduce her political worktime. Thus, both effects are ambiguous. ${ }^{4}$ In the appendix, we show that the same logic applies for an increase in the out-of-office wage rate $\omega$.

The focus of our paper is on the link between 'market conditions' for politicians and income. We ask how competitive pressure affects the actual income of politicians. A crucial indicator of competition may be the (competitive) advantage of one politician over another. The appendix shows that, using equation (2), the effect of an increase in the exogenously given voting advantage $\mu$ on the time spent for outside occupations $t_{1}^{A}$ can be expressed as

$$
\frac{d t_{1}^{A}}{d \mu}=\frac{\Phi^{\prime \prime} f^{\prime}\left(U^{A, e}-U^{A, n e}\right)}{\left(w^{A}\right)^{2} U_{C_{1} C_{1}}^{A}}, \quad \frac{d t_{1}^{B}}{d \mu}=\frac{\Phi^{\prime \prime} f^{\prime}\left(U^{B, e}-U^{B, n e}\right)}{\left(\omega^{B}\right)^{2} U_{C_{1} C_{1}}^{B}}
$$

$\Phi^{\prime \prime}$ is the slope of the density function. If we assume that small $\varepsilon$ (in absolute terms) are more likely than large deviations from the expected value of the voting result, as in figure 1, then $\Phi^{\prime \prime}>0$ for $\mu>0$ and vice versa. This means that an increase in an already existing (dis)advantage decreases $t_{1}^{A}$ and $t_{1}^{B}$. The reason is that it becomes less probable that $A$ loses (wins) the election. Therefore she can "afford" spending time on increasing her outside earnings. If, however, the (dis-)advantage is decreased in absolute terms, i.e. if $\mu$ approaches zero, political effort, $t_{1}^{A}$ and $t_{1}^{B}$, is increased because its expected pay-off rises.

According to equation (5), the model predicts that a decrease (increase) in political competition will result in an increase (decrease) in politicians' outside earnings. Put differently, if the difference to the competitor's expected voting result is reduced in absolute terms, both candidates political effort increases. This distance is interpreted as a measure for political competition. Competition and, thus, political effort is c.p. at its maximum if both competitors have an expected voting result of $50 \%$, i.e. if the distance is zero. In the empirical analysis, we will use this prediction of the model and take past election results as a proxy for the expected voting result. Our main hypothesis is that a given politician has less outside earnings than her twin if she is subject to a higher degree of political competition.

\section{Empirical approach}

The empirical analysis is tailored to test the main implication of the model presented in the previous section. In particular, we want to estimate how outside earnings of professional politicians

\footnotetext{
${ }^{4}$ This trade-off has already been analyzed by Gagliarducci et al. (2007a, 2007b).
} 
react to varying degrees of electoral competition. As we have previously shown, our model predicts a negative impact of electoral competition on politicians' time allocated to outside work, and thus outside earnings. Nevertheless, it is an empirical question whether this relationship can be substantiated based on real data. We proceed as follows. First, we briefly describe the institutional background, with a focus on the federal electoral system in Germany. We then discuss our estimation approach, focussing on the potential endogeneity of our measure of electoral competition and the suggested solution to this problem. Finally, we briefly present and describe the data.

\subsection{Institutional background}

The federal parliament of Germany, the Bundestag, is the legislative branch of the German federal political system (together with the Bundesrat, representing the state governments). The Bundestag is elected every four years. Each citizen has two different votes, a first vote and a second vote. The first vote is directly attributed to a candidate representing the electoral district. In each electoral district, the candidate obtaining the majority of first votes is elected to the Bundestag by a direct mandate. This part of the election has features of the majority voting system. With the second vote the elector votes for a party which may then, according to its share of party votes, send candidates from predefined electoral lists into the Bundestag, which has the feature of proportional representation. These electoral lists contain party candidates in a predefined order. While each directly elected candidate represents one of the 299 electoral districts, candidates on the party lists can only capture the remaining seats of the Bundestag in accordance with the overall vote share of their party. The position of candidates on the party lists is subject to ballot votes taking place on party conventions. There is a minimum threshold of either $5 \%$ of the national party vote or three direct mandates. ${ }^{5}$

\subsection{Estimation approach}

We take a straightforward approach to test the empirical implication of the theoretical model. The population of politicians used to estimate the relation between electoral competition and outside earnings consists of members of the Bundestag. The dependent variable is the amount of annual outside earnings reported by individual members of parliament (MP, henceforth). Our key explanatory variable is the degree of electoral competition, measured by the vote margin

\footnotetext{
${ }^{5}$ In case that a party has less than $5 \%$ votes but three direct mandates, its number of parliament members is according to its vote share (proportional representation).
} 
in the preceding federal election. The vote margin is defined as the difference between the share of first votes that a given MP has received in his electoral district and the vote share of the runner-up. Using a measure for electoral competition based on the outcomes of the last preceding election means that politicians are assumed to form expectations on the degree of competition in coming elections based on outcomes of past electoral races.

The main difficulty when estimating the impact of electoral competition on outside earnings is the fact that a MP's ability to earn income from outside work is not only related to the tradeoff between additional income and deteriorating reelection prospects, but will also depend on personal characteristics affecting the productivity of outside work. We account for this by including a vector of additional explanatory variables in our estimation equation. In particular, we extensively control for personal characteristics that might affect the productivity of MPs in generating outside earnings. However, there is no guarantee that including observable characteristics on the right-hand side of an estimation equation relating outside earnings to electoral competition will suffice to provide us with reliable point estimates. The reason for this is that there might be unobservable characteristics that affect the ability to earn market income and, at the same time, correlate with electoral success. To give a straightforward example, some MPs may simply be smarter than others, making them more successful in terms of election outcomes and in terms of generating outside earnings. Since the error term in our estimation equation will account for all unexplained variation in outside earnings, the fact that smartness is (at least to some extent) unobservable will induce correlation between the residual and electoral competition as our key explanatory variable. This correlation will render naive coefficient estimates inconsistent. As described below, we will use instrumental variables (IVs) to overcome the potential endogeneity problem.

Based on the comparative statics of our theoretical model, we consider the following linear equation that relates reported outside earnings to the degree of electoral competition and controls

$$
y_{i}=\alpha+\beta c_{i}+\delta X_{i}+\epsilon_{i}
$$

where $y_{i}$ denotes outside earnings, $c_{i}$ is electoral competition, $X_{i}$ is the vector of control variables, and $\epsilon_{i}$ is a residual. To obtain a reasonable measure for $c_{i}$, we restrict our attention to those MPs who directly represent an electoral district, i.e. who obtained a majority of first votes within their electoral district. This provides us with a sample of 299 MPs who are homogenous in the sense that their perceptions regarding the probability of reelection in coming elections can reasonably be assumed to depend on the district-level degree of competition in the preceding election. As mentioned above, as our measure for the district-level degree of electoral competition we use the vote margin, defined as the difference between the share of first votes 
of directly elected MPs and the vote share of the runner-up within the electoral district. ${ }^{6}$

Regarding the vector of control variables, $X_{i}$, we collected data on MPs' personal characteristics such as age, number of terms served, gender, educational attainment, indicators for family status, religious orientation, and a broad range of indicators for MPs' occupation before they started their political career. In addition, we include a full series of state dummies to allow for common regional shocks that might affect the ability to raise income from outside work and to account for a potential impact of regional traditions and beliefs regarding the tradeoff between political effort and outside work. Note in particular that the state dummies will fully account for any difference in outside earnings between East and West Germany. The control variables and variables of main interest will be discussed in more detail in the following subsection.

As discussed above, we suspect that unobserved factors driving both outside earnings and our measure of electoral competition induce correlation between the residual, $\epsilon_{i}$, and $c_{i}$. To deal with this problem, we employ a vector of instrumental variables, $Z_{i}$, and estimate the coefficients in equation (6) by two-stage least squares (2SLS). To be valid instruments, variables must fulfill three conditions: they must be strongly (partially) correlated with $c_{i}$ once the exogenous explanatory variables are netted out; they must be exogenous in the structural equation, i.e. the elements of $Z_{i}$ must be uncorrelated with $\epsilon_{i}$; and they must be validly excluded from the structural equation.

Our choice of $Z_{i}$ rests on the institutional characteristics of the federal electoral system in Germany. In particular, we exploit the fact that voters vote on district-level candidates (first vote) and parties (second vote) at the same time. Recall that candidates who are directly elected by obtaining a majority of (district-level) first votes become members of the Bundestag irrespective of their party's overall second-vote share. We exploit this institutional feature and construct a first instrument, $z_{i 1}$, as the share of second votes MP $i$ 's party has obtained within $i$ 's electoral district in the last preceding election. $z_{i 1}$ lends itself as an instrument for $c_{i}$ because both the share of first votes of a given candidate and the share of second votes of the candidate's party will be correlated due to voters casting both of their votes according to party preferences. Moreover, since the second vote should only reflect party preferences, $z_{i 1}$ should not be correlated with the residual. The fact that $c_{i}$ is defined as the first-vote margin over the runner-up suggests to define a second instrument, $z_{i 2}$, as the share of second votes received by the party represented by the first-vote runner-up in the next preceding election.

\footnotetext{
${ }^{6}$ We also experimented with various measures describing the degree of effective electoral competition for MPs who are elected through party lists. However, we found it difficult to obtain robust empirical evidence. This may have to do with the problem that, while we only observe a given MPs position on the relevant list in past elections, the behavior regarding outside work should depend on politicians' expectations on their position in coming election.
} 
While $z_{i 1}$ should be positively correlated with $c_{i}$, the correlation between $c_{i}$ and $z_{i 2}$ should be negative. Using multiple instruments for a single troublesome variable is attractive for two reasons. Firstly, it typically helps to reduce the standard error of the 2SLS estimates. Secondly, it allows us to run a test of overidentifying restrictions. The joint null hypothesis is that $z_{i 1}$ and $z_{i 2}$ are valid instruments, i.e., uncorrelated with the error term, and that they are correctly excluded from the estimated equation.

\subsection{Data}

In the following, we discuss the the data and present summary statistics. Since our empirical analysis will be concerned only with the 299 directly elected members of the Bundestag, we report summary statistics only for this subsample of all MPs. Recall that we exclude MPs that have been elected through party lists to obtain a sample of politicians with homogenous perceptions of electoral competition.

Our key variables are outside earnings and electoral competition. The information on outside earnings is obtained from Bundestag (2007). In 2005, the Bundestag decided to publish an annual report on outside earnings received by the members of Parliament. ${ }^{7}$ From 2005 on, each MP has to report the number and earnings class of his or her outside occupations. However, due to a lawsuit the data was published as recently as summer 2007 for the years 2005-2007. ${ }^{8}$

The report on individual outside earnings classifies each individual job into one of four different categories: regular occupation, position in a company in the private sector, position in a company in the public sector and position in a non-profit association. For each category, we have the number of jobs and for each job the information if it is either one-time or at regular intervals, and the amount of payments received according to four intervals $[0 ; 1,000)$, $[1,000 ; 3,500),[3,500 ; 7,000),[7,000, \infty)$. Assuming an upper bound of 12,000 Euros for the highest interval, we calculated the amount of outside earnings for each individual MP by using average values for each income category (i.e. 500; 2, 250; 5, 250; 9, 500).

Regarding electoral competition, the German electoral system suggests to use the first-vote margin. As mentioned above, it is defined as the difference between the vote share that a given MP has received in his electoral district and the vote share of the runner-up. The data

\footnotetext{
${ }^{7}$ Cf. Bundestag (2006).

${ }^{8}$ The information on outside earnings is available on the website of each MP at http://www.bundestag.de/htdocs e/members/mdb/index.html and it is updated in irregular intervals. We collected this data in fall 2007 and updated the information in the beginning of 2008 to include all outside earnings from 2005-07.
} 
refer to the 2005 election and are obtained from Bundeswahlleiter (2005). Table 1 shows descriptive statistics for our key variables. The average directly elected candidate receives outside earnings of about 10, 500 Euros per year. The standard deviation of more than 25, 250 Euros indicates that the variation across MPs is quite substantial. The average first-vote margin is 13.7 percentage points. Again, there is significant variation across politicians.

Table 1: Descriptives on key variables

\begin{tabular}{lrrrr}
\hline Variable & Mean & Std. Dev. & Min & Max \\
\hline Outside earnings & 10501 & 25254 & 0 & 144500 \\
Vote margin (first votes, in \%) & 13.7 & 10.5 & 0.1 & 48.1 \\
\hline Notes: & & & & \\
Only directly elected candidates included $(\mathrm{N}=299)$. & & &
\end{tabular}

Regarding our control variables, we have collected information on personal characteristics (education, family status etc.) as well as political variables (party affiliation, number of terms served, etc.). Table 2 reports some descriptive statistics. For each variable, we display the number of MPs, the fraction of MP with strictly positive outside earnings, and the mean income in all relevant categories.

A few details stand out. Firstly, male MPs have outside earnings that are more than four times higher than female MPs. Secondly, the income of MPs with a leading position within the party or the Parliament, i.e. the (vice) chairman of a party or Parliament committee, is substantially higher compared to the income of common members of the Bundestag. Thirdly, Christian Democrats have significantly higher outside earnings than politicians from all other parties. 
Table 2: Descriptives on personal and political characteristics

\begin{tabular}{|c|c|c|c|}
\hline Variable & Frequency & $\%$ outside earnings $>0$ & Mean income \\
\hline \multicolumn{4}{|l|}{ Sex } \\
\hline Male & 229 & 0.86 & 12740 \\
\hline Female & 70 & 0.80 & 3178 \\
\hline \multicolumn{4}{|l|}{ Leading position } \\
\hline 0 & 194 & 0.82 & 6073 \\
\hline 1 & 105 & 0.90 & 18684 \\
\hline \multicolumn{4}{|l|}{ Education } \\
\hline Less than high school & 32 & 0.88 & 16447 \\
\hline High school & 17 & 0.71 & 5000 \\
\hline University & 196 & 0.85 & 9709 \\
\hline Ph.D. & 54 & 0.87 & 11587 \\
\hline \multicolumn{4}{|l|}{ Family status } \\
\hline single & 53 & 0.79 & 5128 \\
\hline single parent & 25 & 0.80 & 7370 \\
\hline married & 42 & 0.79 & 7553 \\
\hline married with children & 179 & 0.88 & 13222 \\
\hline \multicolumn{4}{|l|}{ Sector } \\
\hline Private & 117 & 0.85 & 11717 \\
\hline Public & 107 & 0.79 & 6834 \\
\hline Business & 5 & 1.00 & 8166 \\
\hline Politics & 70 & 0.91 & 14241 \\
\hline \multicolumn{4}{|l|}{ Party } \\
\hline Christian Democrats & 149 & 0.89 & 13150 \\
\hline Social Democrats & 145 & 0.79 & 7980 \\
\hline Greens & 1 & 1.00 & 1000 \\
\hline Socialists & 3 & 1.00 & 7333 \\
\hline Independent & 1 & 1.00 & 500 \\
\hline \multicolumn{4}{|l|}{ Terms } \\
\hline 1 & 43 & 0.79 & 12317 \\
\hline 2 & 95 & 0.79 & 7015 \\
\hline 3 & 61 & 0.92 & 8639 \\
\hline 4 & 33 & 0.88 & 19808 \\
\hline 5 & 67 & 0.88 & 11391 \\
\hline
\end{tabular}

Notes:

Only directly elected candidates included $(\mathrm{N}=299)$. 


\section{Empirical results}

We start the discussion of our empirical results with a set of OLS regressions reported in Table 3. The dependent variable is reported outside earnings of directly elected members of the Bundestag. Specification (1) is a baseline specification with only a subset of our control variables included. The reported coefficients indicate that an increase in the first-vote margin by one percentage point triggers an increase in outside earnings of about 340 Euros. Furthermore, we find that MPs with leading positions have significantly higher outside earnings. Our baseline model also points to female MPs receiving substantially lower income from outside work compared to their male colleagues.

Table 3: Impact of electoral competition on outside earnings (OLS)

\begin{tabular}{|c|c|c|}
\hline \multicolumn{3}{|c|}{ Dependent variable: Outside earnings of directly elected Members of Parliament } \\
\hline \multirow[t]{2}{*}{ Vote margin } & $340.2^{\star \star}$ & $516.1^{\star \star \star}$ \\
\hline & $(166.2)$ & $(184.4)$ \\
\hline \multirow[t]{2}{*}{ Leading position } & $12,953^{\star \star \star}$ & $11,699^{\star \star \star}$ \\
\hline & $(3,612)$ & $(3746)$ \\
\hline \multirow[t]{2}{*}{ Female } & $-8,181^{\star \star \star}$ & $-7,191^{\star \star}$ \\
\hline & $(2,127)$ & $(2,869)$ \\
\hline \multirow[t]{2}{*}{ Age } & 21.84 & 803.2 \\
\hline & $(159.9)$ & $(1,901)$ \\
\hline \multirow[t]{2}{*}{ High school } & $-7,233$ & $-7,761$ \\
\hline & $(5,998)$ & $(6,636)$ \\
\hline \multirow[t]{2}{*}{ University } & $-6,050$ & $-1,571$ \\
\hline & $(5,307)$ & $(5,465)$ \\
\hline \multirow[t]{2}{*}{ Ph.D. } & $-5,741$ & $-3,513$ \\
\hline & $(6,199)$ & $(6,986)$ \\
\hline$\overline{R^{2}}$ & 0.113 & 0.242 \\
\hline $\mathrm{N}$ & 299 & 299 \\
\hline Additional controls & constant & see notes below \\
\hline
\end{tabular}

Notes:

Sample includes only directly elected MPs. Dependent variable is average annual outside earnings reported for the years 2005-2007, measured in Euro. Standard errors (robust to heteroscedasticity) in parentheses. Additional controls in specification (2): Constant, age squared, number of terms served, dummy variables for family status (married/no children, married/having children), occupation before started political career (public service clerk, company employee, civil servant, freelancer, officer, manager, attorney, teacher, politician (general), politician (local level)), political party, and a full series of state dummies.

$\star \star \quad 5 \%$ significance level.

$\star \star \star 1 \%$.significance level.

The second column reports a baseline model with a substantial number of additional control variables (coefficients not reported, see bottom of table for a list of additional controls included). While the coefficients of leading position and the dummy for female politicians are very similar to those obtained before, our main coefficient of interest is now substantially larger, suggesting 
that a one percentage-point increase in the vote margin increases outside earnings by 516 Euros per year. ${ }^{9}$ If the vote margin increases by one standard deviation, a MP will benefit from this decrease in electoral competition by an increase in outside earnings of about 5,444 Euros per year. Assuming that this effect is constant over time, over a four-year term this would amount to 21,800 Euros.

So far we have ignored the main identification problem, i.e. the potential endogeneity of the firstvote margin as our measure for electoral competition. Table 4 reports results for instrumental variables estimations that account for this problem.

Table 4: Impact of electoral competition on outside earnings (2SLS)

\begin{tabular}{lccc}
\hline \multicolumn{2}{l}{ Dependent variable: Outside earnings of directly elected } & Members of & Parliament \\
& $(1)$ & $(2)$ & $(3)$ \\
\hline Vote margin & $455.1^{\star \star}$ & $427.2^{\star \star}$ & $445.2^{\star \star \star}$ \\
& $(184.4)$ & $(169.4)$ & $(167.9)$ \\
Leading position & $11,538^{\star \star \star}$ & $11,500^{\star \star \star}$ & $11,525^{\star \star \star}$ \\
& $(3,476)$ & $(3420)$ & $(3,456)$ \\
Female & $-7,363^{\star \star \star}$ & $-7,461^{\star \star \star}$ & $-7,398^{\star \star \star}$ \\
& $(2,583)$ & $(2732)$ & $(2,628)$ \\
\hline$R^{2}$ & 0.241 & 0.242 & 0.242 \\
$\mathrm{~N}$ & 299 & 299 & 299 \\
Additional controls & yes & yes & yes \\
\hline Hansen test of overident. restr. ( $p$-value) & - & - & 0.831 \\
$F-$ Statistic for joint significance of IVs & 682.94 & 398.96 & 681.87 \\
Coefficients of IVs (1 ${ }^{\text {st }}$ stage): & & & \\
Second-vote share own party & 1.61 & - & 1.13 \\
& $(0.06)$ & & $(0.09)$ \\
Second-vote share runner-up party & - & -1.87 & -0.87 \\
& & $(0.09)$ & $(0.10)$ \\
\hline
\end{tabular}

Notes:

Sample includes only directly elected MPs. Dependent variable is average annual outside earnings reported for the years 2005-2007, measured in Euro. Standard errors (robust to heteroscedasticity) in parentheses. Additional controls: Constant, age, age squared, dummies for educational attainment (high school, university, Ph.D.), number of terms served, dummy variables for family status (married/no children, married/having children), occupation before started political career (public service clerk, company employee, civil servant, freelancer, officer, manager, attorney, teacher, politician (general), politician (local level)), political party, and a full series of state dummies.

$\star \star \quad 5 \%$ significance level.

$\star \star \star 1 \%$.significance level.

We show three specifications that differ in terms of the instruments actually employed in the first stage regression. Column (1) depicts the results for a 2SLS estimation where we have instrumented the first-vote margin with the share of second votes of a politician's own party,

\footnotetext{
${ }^{9}$ Recall that we have calculated outside earnings using the mean income for each of the various income categories. Using the lower (upper) bound instead changes the coefficients to 353.6 (678.6). In both cases, they remain significant at the $1 \%$-level.
} 
$z_{1}$. Note that with a single IV, the coefficient of the first-vote margin is exactly identified, and we cannot test for instrument validity. Note, however, that the $z_{1}$ is strongly partially correlated with our measure for electoral competition, with a coefficient of 1.61 and a standard error of 0.06 in the first stage regression. Moreover, the corresponding $F$-statistic of the first stage regression is about 683 , suggesting that $z_{1}$ is a strong instrument for the first-vote margin. Turning to our key variable of interest, we note that the coefficient of electoral competition is only slightly smaller than the corresponding value in the baseline OLS estimation. Calculated over a four-year term, we still find that a one-standard deviation increase in the first-vote margin triggers a remarkable increase in outside earnings of about 19,200 Euros. Note also that the point estimate is almost significant at the $1 \%$ level.

Column (2) further substantiates our main result. Keeping the specification of the main regression constant, the only change compared to column (1) is the use of our second IV, i.e. the share of second votes received by the party represented by the first-vote runner-up, $z_{2}$. A quick inspection of the results reveals that relying on $z_{2}$, we obtain very similar results compared to the previous estimation. Note that the partial correlation between the IV and the first-vote margin is again strong, with a coefficient of -1.87 and a standard error of 0.09 . However, the $F$-statistic of the first-stage regression suggests that $z_{1}$ is the stronger IV compared to $z_{2}$. While this is in line with our expectations, the large value of the $F$-statistic from both 2SLS estimations makes us confident that the analysis does not suffer from a weak instruments problem.

As discussed above, it is attractive to use multiple instruments (if available), as the overidentification of the endogenous explanatory variable allows to test for the validity of the IVs. To do so, we re-estimated our model using both $z_{1}$ and $z_{2}$ as IVs for the politicians' first-vote margin. Investigating the outcome reported in Column (3), we first note that both IVs pass our series of tests regarding instrument quality. In particular, we find that both $z_{1}$ and $z_{2}$ show a strong partial correlation with the endogenous variable, with the coefficients in the first stage regression carrying the expected sign. Secondly, we note that the $F$-statistic for joint significance of the IVs in the first stage is 682, confirming again that we do not rely on weak instruments. Finally, we cannot reject the null hypothesis of the Hansen test of overidentifying restrictions at any reasonable level of significance. Hence, our IVs pass the standard test of instrument validity without any difficulty.

Turning to the coefficient estimates, we find that the results of the previously reported 2SLS estimations are confirmed. In particular, our coefficient of main interest is very close to the levels obtained before. Interestingly, by exploiting the variation from both IVs, we are now able to reject the null of no effect of electoral competition on politicians' outside earnings at a 
noticeable $1 \%$ level of significance.

To summarize our empirical results, we find strong evidence suggesting that MPs benefit from low levels of electoral competition. In particular, and in accordance with our theoretical model, our data suggest that outside earnings are significantly higher if electoral competition is low. Noting the likely endogeneity of our measure of electoral competition, we have employed instrumental variables to identify the impact of first-vote margins on outside earnings of members of the German Bundestag. As expected, the 2SLS estimation results regarding the effect of electoral competition on outside earnings are somewhat smaller than compared to a naive estimation approach. However, the quantitative difference between OLS and 2SLS estimations is relatively small.

\section{Conclusion}

Due to asymmetric information between voters and elected representatives, the quality of policymaking crucially depends on the incentives of elected politicians to align their actions with the interests of voters as their principals. Among the various forms of interaction between voters and elected officials, elections are certainly the most important incentive-setting mechanism. However, there is surprisingly little micro-evidence on how politicians react to varying degrees of electoral competition.

This paper adds to the literature in providing evidence on the link between electoral competition and politicians' outside income. Exploiting the remarkable variation in reported outside earnings in a new data set covering the members of the German Bundestag, we have asked how outside earnings of MPs who represent electoral districts and are elected by majority rule react to electoral competition. In accordance with the predictions of a simple theoretical model focussing on the tradeoff between outside work and reelection prospects, our results point to a significant negative impact of competition on MPs' private sector activities. We find that a ten-percentage-point decrease in the vote margin decreases annual outside income over a fouryear term by 18,000 to 19,200 Euros on average. To account for the likely endogeneity of our measure for electoral competition, we have employed instrumental variables that are motivated by the specific institutional details of the German electoral system.

To the best of our knowledge, this paper is the first to provide micro-evidence on the effectiveness of competitive pressure in driving down politicians' outside income. However, our findings fit nicely to evidence reported in related work. In particular, they are complementary to the 
evidence in Gagliarducci et al. (2007b) on a positive relation between electoral competition and political effort in terms of session attendance. Thus, in the light of evidence presented in related studies, our findings point to politicians behaving in a way as it is implied by our theoretical model: When political competition gets stronger, the tradeoff between outside income and reelection prospects forces politicians to invest more in political activities and, at the same time, to reduce activities that generate outside earnings.

Though it is tempting to draw the conclusion that an increase in electoral competition would benefit voters, we would like to point to two caveats: Firstly, we have ignored the impact of electoral competition on the self-selection of citizens into political careers. It may well be the fact that increased competition reduces the average ability of elected politicians. Secondly, while our data suggest that politicians devote less time to private sector activities, we do not directly observe whether politicians increase socially productive or socially unproductive political work in response (for instance, think of parliamentary work vs. campaigning). Depending on what type of activity benefits most from the reduction in private sector work, the impact on the welfare of voters may be quite different. Hence, there remains plenty of scope for future research on the role of incentives in the political sphere.

\section{References}

Besley, T.J. (2004), "Paying Politicians: Theory and Evidence", Journal of the European Economic Association, Vol. 2, 2-3, 193-215.

Besley, T.J. (2005), "Political Selection", Journal of Economic Perspectives, Vol. 19, 3, 43-60.

Bundestag (2006), "Act on the Legal Status of Members of the German Bundestag", http://www.bundestag.de/htdocs_e/parliament/function/legal/memlaw.pdf.

Bundestag (2007), "Members of the German Bundestag, http://www.bundestag.de/htdocs_e/members/mdb/index.html."

Bundeswahlleiter (2005), "Bundestagswahl 2005",

http://www.bundeswahlleiter.de/bundestagswahl2005/.

Caselli, F. and M. Morelli (2004), "Bad Politicians", Journal of Public Economics, Vol. 88, 3-4, 759-782.

Couch, J.F., K.E. Atkinson and W.F. Shughart II (1992), "Ethic Laws and the Outside Earnings 
of Politicians: the Case of Alabama's "Legislator-Educators"”, Public Choice, Vol.73, 2, 135145 .

Fiorina, M.P. (1994), "Divided Government in the American States: A Byproduct of Legislative Professionalism?", American Political Science Review, Vol. 88, 2, 304-316.

Gagliarducci, S., T. Nannicini and P. Naticchioni (2007a): Outside Income and Moral Hazard: The Elusive Quest for Good Politicians, Working Paper.

Gagliarducci, S., T. Nannicini and P. Naticchioni (2007b): Electoral Rules and Politicians' Behavior: A Micro Test, Working Paper.

Kunicova, J. and S. Rose-Ackerman (2005), "Electoral Rules as Constraints on Corruption", British Journal of Political Science, Vol. 34, 4, 573-606.

Mattozzi, A. and A. Merlo (2007a), "Political Careers or Career Politicians", NBER Working Paper No. W12921.

Mattozzi, A. and A. Merlo (2007b), "Mediocracy", NBER Working Paper No. W12920.

Messner, M. and M. Polborn (2004), "Paying Politicians", Journal of Public Economics, Vol. 88, $12,2423-2445$.

Milesi-Ferretti, G.M., R. Perotti, and M. Rostagno (2002), "Electoral Systems and Public Spending", Quarterly Journal of Economics, Vol. 117, 2, 609-657.

Myerson, R.B. (1993), "Effectiveness of the Electoral Systems for Reducing Government Corruption: A Game-Theoretic Analysis", Games and Economic Behavior, Vol. 5, 118-132.

Parker, G.R. (1992), "The Distribution of Honoraria Income in the U.S. Congress: Who Gets Rents in Legislatures and Why", Public Choice, Vol. 73, 2, 167-181.

Persson, T. and G. Tabellini (1999), "Political Economics", MIT Press.

Persson, T. and G. Tabellini (2000), "The Size and Scope of Government: Comparative Politics with Rational Politicians", European Economic Review, Vol. 43, 699-735.

Persson, T. and G. Tabellini (2003), "The Economic Effects of Constitutions", MIT Press.

Poutvaara, P. and Takalo, T. (2007), "Candidate Quality", International Tax and Public Finance, Vol. 14, 1, 7-27.

Rosenson, B.A. (2007), “Explaining Legislators' Positions on Outside Income Limits: Voting 
on Honoraria Ceilings in the U.S. Senate, 1981-1983", Public Choice, Vol.133, 1-2, 111-128.

\section{Acknowledgements}

We thank Clemens Fuest for valuable comments. All errors remain our own.

\section{Appendix}

This appendix derives the comparative statics results discussed in section 2 .

Optimal choices of $t^{A}$ and $t^{B}$ are given by $\frac{\partial E\left(U^{A}\right)}{\partial t_{1}^{A}}=-w^{A} U_{C_{1}^{A}}^{A}+\Phi^{\prime} f^{\prime}\left(U^{A, e}-U^{A, n e}\right)=0$ for candidate $\mathrm{A}$ and $\frac{\partial E\left(U^{B}\right)}{\partial t_{1}^{B}}=-\omega^{B} U_{C_{1}^{B}}^{B}+\Phi^{\prime} f^{\prime}\left(U^{B, e}-U^{B, n e}\right)=0$ for candidate B, with $\Phi^{\prime}=\Phi^{\prime}\left(-\mu-f\left(t_{1}^{A}-t_{1}^{B}\right)\right)$ and $f^{\prime}=f^{\prime}\left(t_{1}^{A}-t_{1}^{B}\right)$. Differentiating both equations with respect to $t^{A}, t^{B}$ and an exogenous parameter $y$ gives:

$$
\frac{d t_{1}^{A}}{d y}=-\frac{\frac{\partial^{2} E\left(U^{A}\right)}{\partial t_{1}^{A} \partial y} \frac{\partial^{2} E\left(U^{B}\right)}{\partial\left(t_{1}^{B}\right)^{2}}-\frac{\partial^{2} E\left(U^{B}\right)}{\partial t_{1}^{B} \partial y} \frac{\partial^{2} E\left(U^{A}\right)}{\partial t_{1}^{A} \partial t_{1}^{B}}}{\frac{\partial^{2} E\left(U^{A}\right)}{\partial\left(t_{1}^{A}\right)^{2}} \frac{\partial^{2} E\left(U^{B}\right)}{\partial\left(t_{1}^{B}\right)^{2}}-\frac{\partial^{2} E\left(U^{A}\right)}{\partial t_{1}^{A} \partial t_{1}^{B}} \frac{\partial^{2} E\left(U^{B}\right)}{\partial t_{1}^{B} \partial t_{1}^{A}}}
$$

and, equivalently,

$$
\frac{d t_{1}^{B}}{d y}=-\frac{\frac{\partial^{2} E\left(U^{B}\right)}{\partial t_{1}^{B} \partial y} \frac{\partial^{2} E\left(U^{A}\right)}{\partial\left(t_{1}^{A}\right)^{2}}-\frac{\partial^{2} E\left(U^{A}\right)}{\partial t_{1}^{A} \partial y} \frac{\partial^{2} E\left(U^{B}\right)}{\partial t_{1}^{B} \partial t_{1}^{A}}}{\frac{\partial^{2} E\left(U^{A}\right)}{\partial\left(t_{1}^{A}\right)^{2}} \frac{\partial^{2} E\left(U^{B}\right)}{\partial\left(t_{1}^{B}\right)^{2}}-\frac{\partial^{2} E\left(U^{A}\right)}{\partial t_{1}^{A} \partial t_{1}^{B}} \frac{\partial^{2} E\left(U^{B}\right)}{\partial t_{1}^{B} \partial t_{1}^{A}}}
$$

It follows from (2) that $\frac{\partial^{2} E\left(U^{A}\right)}{\partial\left(t_{1}^{A}\right)^{2}}=\left(w^{A}\right)^{2} U_{C_{1}^{A} C_{1}^{A}}^{A}-\left(\Phi^{\prime \prime}\left(f^{\prime}\right)^{2}-\Phi^{\prime} f^{\prime \prime}\right)\left(U^{A, e}-U^{A, n e}\right), \frac{\partial^{2} E\left(U^{B}\right)}{\partial\left(t_{1}^{B}\right)^{2}}=$ $\left(\omega^{B}\right)^{2} U_{C_{1}^{B} C_{1}^{B}}^{B}+\left(\Phi^{\prime \prime}\left(f^{\prime}\right)^{2}-\Phi^{\prime} f^{\prime \prime}\right)\left(U^{B, e}-U^{B, n e}\right), \frac{\partial^{2} E\left(U^{A}\right)}{\partial t_{1}^{A} \partial t_{1}^{B}}=\left(\Phi^{\prime \prime}\left(f^{\prime}\right)^{2}-\Phi^{\prime} f^{\prime \prime}\right)\left(U^{A, e}-U^{A, n e}\right)$ and $\frac{\partial^{2} E\left(U^{B}\right)}{\partial t_{1}^{B} \partial t_{1}^{A}}=-\left(\Phi^{\prime \prime}\left(f^{\prime}\right)^{2}-\Phi^{\prime} f^{\prime \prime}\right)\left(U^{B, e}-U^{B, n e}\right)$.

Under symmetry, this implies $\frac{\partial^{2} E\left(U^{A}\right)}{\partial\left(t_{1}^{A}\right)^{2}} \frac{\partial^{2} E\left(U^{B}\right)}{\partial\left(t_{1}^{B}\right)^{2}}-\frac{\partial^{2} E\left(U^{A}\right)}{\partial t_{1}^{A} \partial t_{1}^{B}} \frac{\partial^{2} E\left(U^{B}\right)}{\partial t_{1}^{B} \partial t_{1}^{A}}=\left(w^{2} U_{C_{1} C_{1}}\right)^{2}$ and $\frac{\partial^{2} E\left(U^{A}\right)}{\partial\left(t_{1}^{A}\right)^{2}}-$ $\frac{\partial^{2} E\left(U^{B}\right)}{\partial t_{1}^{B} \partial t_{1}^{A}}=\frac{\partial^{2} E\left(U^{B}\right)}{\partial\left(t_{1}^{B}\right)^{2}}-\frac{\partial^{2} E\left(U^{A}\right)}{\partial t_{1}^{A} \partial t_{1}^{B}}=w^{2} U_{C_{1} C_{1}}$, where we omitted candidate indices according to the symmetry assumption. 
Now, consider the impact of a small increase in the politician's official compensation $W$. We therefore need $\frac{\partial^{2} E\left(U^{A}\right)}{\partial t_{1}^{A} \partial W}=-w^{A} U_{C_{1}^{A} C_{1}^{A}}^{A}+\Phi^{\prime} f^{\prime}\left(U_{C_{2}^{A}}^{A}\right)$ and $\frac{\partial^{2} E\left(U^{B}\right)}{\partial t_{1}^{B} \partial W}=\Phi^{\prime} f^{\prime}\left(U_{C_{2}^{B}}^{B}\right)$, from which follows:

$$
\begin{aligned}
& \frac{d t_{1}^{A}}{d W}=\frac{\partial^{2} E(U)}{\partial\left(t_{1}^{B}\right)^{2}} \frac{1}{w^{3}\left(U_{C_{1} C_{1}}\right)}-\frac{\Phi^{\prime} f^{\prime}\left(U_{C_{2}}\right)}{U_{C_{1} C_{1}} w^{2}}>0 \\
& \frac{d t_{1}^{B}}{d W}=-\frac{\partial^{2} E(U)}{\partial t_{1}^{B} \partial t_{1}^{A}} \frac{1}{w^{3}\left(U_{C_{1} C_{1}}\right)}-\frac{\Phi^{\prime} f^{\prime}\left(U_{C_{2}}\right)}{U_{C_{1} C_{1}} w^{2}}>0
\end{aligned}
$$

Consider now the impact of a small increase in the politician's outside compensation $w^{A}$. We therefore need $\frac{\partial^{2} E\left(U^{A}\right)}{\partial t_{1}^{A} \partial w^{A}}=-U_{C_{1}^{A}}^{A}-w^{A}\left(1-t_{1}^{A}\right) U_{C_{1}^{A} C_{1}^{A}}^{A}+\Phi^{\prime} f^{\prime}\left(U_{C_{2}^{A}}^{A}\right)$ and $\frac{\partial^{2} E\left(U^{B}\right)}{\partial t_{1}^{B} \partial w^{A}}=\Phi^{\prime} f^{\prime}\left(U_{C_{2}^{B}}^{B}\right)$, from which follows under symmetry

$$
\begin{aligned}
& \frac{d t_{1}^{A}}{d w}=\left(\frac{U_{C_{1}}+w\left(1-t_{1}^{A}\right) U_{C_{1} C_{1}}}{\left(w^{2} U_{C_{1} C_{1}}\right)^{2}}\right) \frac{\partial^{2} E(U)}{\partial\left(t_{1}^{B}\right)^{2}}-\frac{\Phi^{\prime} f^{\prime} U_{C_{2}}}{w^{2} U_{C_{1} C_{1}}} \\
& \frac{d t_{1}^{B}}{d w}=-\left(\frac{U_{C_{1}}+w\left(1-t_{1}^{A}\right) U_{C_{1} C_{1}}}{\left(w^{2} U_{C_{1} C_{1}}\right)^{2}}\right) \frac{\partial^{2} E(U)}{\partial t_{1}^{B} \partial t_{1}^{A}}-\left(\frac{\Phi^{\prime} f^{\prime}\left(U_{C_{2}}\right)}{w^{2} U_{C_{1} C_{1}}^{B}}\right)
\end{aligned}
$$

To determine the impact of a small increase in the wage rate $\omega^{B}$, we need $\frac{\partial^{2} E(U)}{\partial t_{1}^{A} \partial \omega}=-\Phi^{\prime} f^{\prime}\left(U_{C_{2}^{A}}^{A}\right)$ and $\frac{\partial^{2} E(U)}{\partial t_{1}^{B} \partial \omega}=-U_{C_{1}}^{B}-\omega^{B}\left(1-t_{1}^{B}\right) U_{C_{1}^{B} C_{1}^{B}}^{B}-\Phi^{\prime} f^{\prime}\left(U_{C_{2}^{B}}\right)$, from which follows

$$
\begin{aligned}
\frac{d t_{1}^{A}}{d \omega} & =-\left(\frac{U_{C_{1}}+\omega\left(1-t_{1}^{B}\right) U_{C_{1} C_{1}}}{\left(w^{2} U_{C_{1} C_{1}}\right)^{2}}\right) \frac{\partial^{2} E(U)}{\partial t_{1}^{A} \partial t_{1}^{B}}+\frac{\Phi^{\prime} f^{\prime}\left(U_{C_{2}}\right)}{w^{2} U_{C_{1} C_{1}}} \\
\frac{d t_{1}^{B}}{d \omega} & =\frac{\left(U_{C_{1}}+\omega\left(1-t_{1}^{B}\right) U_{C_{1} C_{1}}\right)}{\left(w^{2} U_{C_{1} C_{1}}\right)^{2}} \frac{\partial^{2} E(U)}{\partial\left(t_{1}^{A}\right)^{2}}+\frac{\Phi^{\prime} f^{\prime}\left(U_{C_{2}}\right)}{w^{2} U_{C_{1} C_{1}}}
\end{aligned}
$$

For the impact of a small increase in the voting advantage $\mu$, we need $\frac{\partial^{2} E(U)}{\partial t_{1}^{A} \partial \mu}=\frac{\partial^{2} E(U)}{\partial t_{1}^{B} \partial \mu}=$ $-\Phi^{\prime \prime} f^{\prime}\left(U^{e}-U^{n e}\right)$, from which follows the equations in the text. In case of asymmetries, i.e. if $w^{i} \neq \omega^{i}$ and/or $W \neq \Omega^{i}$, the above impact of $\mu$ reads

$$
\frac{d t_{1}^{A}}{d \mu}=\frac{\omega^{2} U_{C_{1}^{B} C_{1}^{B}}^{B}}{\frac{\partial^{2} E(U)}{\partial\left(t_{1}^{A}\right)^{2}} \frac{\partial^{2} E(U)}{\partial\left(t_{1}^{B}\right)^{2}}-\frac{\partial^{2} E(U)}{\partial t_{1}^{A} \partial t_{1}^{B}} \frac{\partial^{2} E(U)}{\partial t_{1}^{B} \partial t_{1}^{A}}}\left(U^{A, e}-U^{A, n e}\right) \Phi^{\prime \prime} f^{\prime}
$$


and, equivalently,

$$
\frac{d t_{1}^{B}}{d \mu}=\frac{w^{2} U_{C_{1}^{A} C_{1}^{A}}^{A}}{\frac{\partial^{2} E(U)}{\partial\left(t_{1}^{A}\right)^{2}} \frac{\partial^{2} E(U)}{\partial\left(t_{1}^{B}\right)^{2}}-\frac{\partial^{2} E(U)}{\partial t_{1}^{A} \partial t_{1}^{B} \frac{\partial^{2} E(U)}{\partial t_{1}^{B} \partial t_{1}^{A}}}}\left(U^{B, e}-U^{B, n e}\right) \Phi^{\prime \prime} f^{\prime}
$$

Since the denominator is unambiguously positive ${ }^{10}$, both equations have the same properties as in the symmetric case, especially $\operatorname{sgn} \frac{d t_{1}^{A}}{d \mu}=-\operatorname{sgn} \Phi^{\prime \prime}$ and $\operatorname{sgn} \frac{d t_{1}^{B}}{d \mu}=-\operatorname{sgn} \Phi^{\prime \prime}$. Note that, under conditions of asymmetry, $\Phi^{\prime \prime}$ is not necessarily equal to zero if $\mu=0$ (since $t_{A} \neq t_{B}$ ). This does not affect our results, though, since our theory relies on the relationship between vote margin $\mu+f\left(t_{A}-t_{B}\right)$ and not $\mu$ alone. Thus, all interpretations for the symmetric case apply to the asymmetric case as well.

${ }^{10}$ The denominator reads

$$
\begin{aligned}
& \frac{\partial^{2} E(U)}{\partial\left(t_{1}^{A}\right)^{2}} \frac{\partial^{2} E(U)}{\partial\left(t_{1}^{B}\right)^{2}}-\frac{\partial^{2} E(U)}{\partial t_{1}^{A} \partial t_{1}^{B}} \frac{\partial^{2} E(U)}{\partial t_{1}^{B} \partial t_{1}^{A}} \\
= & \left(w^{A}\right)^{2} U_{C_{1}^{A} C_{1}^{A}}^{A}\left(\omega^{B}\right)^{2} U_{C_{1}^{B} C_{1}^{B}}^{B}+\left(w^{A}\right)^{2} U_{C_{1}^{A} C_{1}^{A}}^{A}\left(\Phi^{\prime \prime}\left(f^{\prime}\right)^{2}-\Phi^{\prime} f^{\prime \prime}\right)\left(U^{B, e}-U^{B, n e}\right) \\
& -\left(\Phi^{\prime \prime}\left(f^{\prime}\right)^{2}-\Phi^{\prime} f^{\prime \prime}\right)\left(U^{A, e}-U^{A, n e}\right)\left(\omega^{B}\right)^{2} U_{C_{1}^{B} C_{1}^{B}}^{B}
\end{aligned}
$$

which can be shown to be always positive. 